\title{
REPRESENTASI PEREMPUAN MUSLIM DALAM KANCAH POLITIK
}

\author{
Bira Farida Nurul Layli ${ }^{1}$ \\ Fakultas Dakwah IAIN Salatiga \\ birrafaridha@gmail.com \\ Muna Erawati ${ }^{2}$ \\ Pusat Studi Gender dan Anak IAIN Salatiga \\ munaerawati@gmail.com
}

\begin{abstract}
ABSTRAK: Realitas politik yang menunjukkan masih rendahnya keterwakilan perempuan di DPRD yaitu masih berada di bawah proporsi. Hal ini menunjukkan bahwa keterwakilan perempuan dalam kehidupan politik kurang diperhatikan. Tuntutan kesetaraan gender juga semakin digencarkan sehingga pemerintah mengeluarkan Undang-Undang Nomor 8 Tahun 2012 dan Peraturan KPU yang beberapa pasalnya mengatur mengenai 30\% keterwakilan perempuan. Kondisi seperti ini jugater jadi di DPRD Kota Salatiga. Pemilu pada tahun 2004, jumlah perempuan yang duduk di kursi legislatif mencapai lima orang. Tahun 2009 menjadi tujuh orang dan tahun 2014 masih mencapai tujuh orang. Permasalahan yang dikaji dalam penelitian ini adalah pertama, bagaimana representasi perempuan muslim di DPRD Kota Salatiga; kedua, bagaimana para legislatif perempuan muslim membangun dan mengembangkan komunikasi politik dengan konstituen dan pemerintah serta tantangan dan hambatan apa saja yang telah dilalui. Penelitian ini menggunakan pendekatan kualitatif. Metode pengumpulan data dalam penelitian ini adalah observasi, wawancara, dan dokumentasi. Teknik pengecekan keabsahan data menggunakan teknik triangulasi sumber. Analisis data menggunakan teknik analisis kualitatif yang terdiri dari pertama, pengumpulan data, kedua, reduksi data, ketiga, penyajian data, dan keempat, penarikan kesimpulan. Hasil penelitian menunjukkan bahwa ada tujuh orang perempuan $(28 \%)$ yang terpilih sebagai anggota DPRD Kota Salatiga pada periode 2014-2019. Hal ini mengindikasikan bahwa keterwakilan perempuan muslim dalam politik sudah cukup baik, hanya saja kiprah dan kontribusinya belum maksimal.
\end{abstract}

\section{Kata Kunci: Representasi perempuan dalam politik, Komunikasi politik perempuan, Kesetaraan gender.}

\section{LATAR BELAKANG}

Perempuan muslim mempunyai dua peran yang sama pentingnya, yaitu peran domestik dan juga peran publik. Peran domestik perempuan muslim dalam istilah gender biasanya diibaratkan dengan wilayah dapur, sumur, dan kasur. Peran domestik perempuan muslim meliputi seluruh kegiatannya di dalam rumah tangga seperti memasak dan menyiapkan makanan, mencuci piring dan juga pakaian, membersihkan rumah, mengasuh dan menjaga anak-anak, mengelola keuangan keluarga dan melayani kebutuhan suami.

Peran publik seorang perempuan muslim berkaitan dengan kegiatan-kegiatan

\footnotetext{
${ }^{1}$ Penulis merupakan dosen pada Fakultas Dakwah IAIN Salatiga

2 Penulis merupakan Kepala Pusat Studi Gender dan Anak IAIN Salatiga
} 
yang dilakukannya di luar rumah atau di luar urusan rumah tangganya. Peran publik perempuan muslim diantaranya adalah sebagai anggota masyarakat dan mengikuti berbagai kegiatan sebagai bentuk aktualisasi diri, ada juga yang menjadi seorang anggota partai politik atau legislatif sebagai pembuktian diri bahwa perempuan muslim mampu bersaing dengan laki-laki dalam kepemimpinan. Tidak ada yang membedakan laki-laki dan perempuan muslim kecuali dalam hal kodrat.

Peran publik bukanlah hal yang baru dalam sejarah kehidupan perempuan muslim. Sejarah telah mencatat beberapa tokoh perempuan muslim yang sukses dalam menjalankan peran publik, salah satunya adalah kepemimpinan Ratu Bilqis dari kerajaan Saba' yang sekarang dikenal dengan negeri Yaman. Dalam kepemimpinannya Ratu Bilqis merupakan sosok ratu yang adil, bijaksana dan sangat pemberani dalam mengambil sebuah keputusan untuk masa depan negaranya. Pada masa Rasulullah juga terdapat tokoh-tokoh perempuan muslim yang ikut terjun dalam peperangan seperti Nusaybah binti Ka'ab yang bertempur ketika Perang Uhud berlangsung. Dalam sejarah Indonesia pun terdapat beberapa pahlawan wanita seperti R.A Kartini, Cut Nyak Dien, Cut Mutia, Dewi Sartika dan lain sebagainya.

Kedudukan dan peranan perempuan di Indonesia telah muncul sejak lama. Begitu banyak tercatat sejumlah tokoh perempuan yang turut memberikan andil dalam aktivitas politik, dengan perjuangan fisik melawan penjajah, serta berbagai bentuk perlawanan yang telah dilakukan untuk memperjuangkan hak-hak perempuan untuk memperoleh pendidikan, peluang kerja yang setara dengan pria, serta bentuk-bentuk kekerasan pada perempuan ${ }^{3}$

Begitu banyak perjuangan tokoh-tokoh perempuan muslim yang berpikir bahwa seharusnya perempuan mempunyai hak-hak dan kesempatan yang sama dengan laki-laki. Terhitung sejak konsep gender berkembang di Indoesia, peran perempuan dalam pembangunan mengalami perubahan yang cukup pesat. Perempuan muslim dapat mengenyam bangku pendidikan tanpa ada batasan apapun yang membuat perempuan mampu bersaing dengan laki-laki dalam segala bidang seperti pekerjaan, organisasi, pemerintah dan juga politik. Banyak perempuan muslim yang kini menduduki jabatan penting dalam pemerintahan. Pun dalam bidang politik, aspirasi perempuan muslim telah mendapatkan tempat tersendiri meskipun belum sepenuhnya terwakili.

Gender adalah suatu konsep yang selalu berusaha membicarakanmasalahmasalah sosial laki-laki dan perempuan secara imbang. Selamaini terkesan seperti membela perempuan dan selalu memperjuangkan hak-hak perempuan, karena secara kuantitas dan kualitas memang kaum perempuan masih tertinggal dan mengalami berbagai kendala untuk menuju kesetaraan dan keadilan gender. Sementara yang dimaksud dengan konsep gender adalah suatu sifat yang melekat pada laki-laki dan perempuan karena dikonstruksikan secara sosial dan kultural ${ }^{4}$

Hukum nasional sudah merumuskan apa makna kesetaraan gender, sepertidiatur dalam Instruksi Presiden Nomor 9 Tahun 2000 tentang kesetaraan

${ }^{3}$ Surbakti, Ramlan. 2010. Memahami Ilmu Politik. Jakarta. Gramedia Pustaka Utama.

${ }^{4}$ Pudji Astuti, Tri Marhaeni. 2011. Konstruksi Gender dalam Realitas Sosial. Semarang: Unnes Press. 


\section{Qawwãm•Volume 13 Nomor 2, Desember 2019}

gender dimana dinyatakan bahwa: kesetaraan gender adalah kesamaan kondisi bagi laki-laki dan perempuan untukmemperoleh kesempatan dan hak-haknya sebagai manusia agar mampu berperandan berpartisipasi dalam kegiatan politik, ekonomi, sosial budaya dan pertahanandan kemanan nasional dan kesamaan dalam menikmati hasil pembangunan ${ }^{5}$

Upaya Negara untuk meningkatkan kesetaraan gender dalam keterwakilan perempuan dalam parlemen, di masa Orde Lama dan Orde Baru (1955-1997) masih belum dilakukan. Tindakan afirmasi terhadap keterwakilan perempuan dalam politik baru terlahir di masa reformasi, tepatnya ketika Pemilu 2004 dengan diterapkannya sistem kuota minimal 30\% keterwakilan perempuan pada saat pencalonan anggota legislatif. Pada Pemilu 2004 ini dilakukan penggabungan sistem kuota dengan aturan nomor urut di dalam Pemilu, namun belum menggunakan zipper system di dalamnya. Zipper system merupakan sistem yang mengatur bahwa setiap tiga bakal calon harus terdapat sekurang-kurangnya satu orang perempuan. Ketentuan ini terdapat dalam Pasal 55 ayat (2) UU No. 10 Tahun 2008. Tujuan utama kebijakan ini adalah untuk menghindari dominasi salah satu jenis kelamin dalam lembaga-lembaga politik yang merumuskan kebijakan publik.

Hal ini menjadi sangat rasional bila melihat pada pemilu tahun 2014, sudah diberlakukan kebijakan penguatan afirmatif kuota $30 \%$ di parlemen yang diatur Undang Undang No. 8 Tahun 2012 tentang Pemilu. Kebijakan ini mewajibkan partai politik mencalonkan sekurang-kurangnya 30\% berjenis kelamin perempuan dari total calon legislatif ditingkat pusat, provinsi, maupun kabupaten/kota. Bagi partai politik yang tidak menjalankannya mendapatkan sanksi tidak ikut dalam pemilu. Hal tersebut diharapkan dapat menjadi tonggak awal bagi negara sebagai upaya meningkatkan keterwakilan perempuan di lembaga-lembaga legislatif, baik di daerah maupun pusat.

Selama ini biasanya perempuan hanya dibutuhkan di bidang politik jika kaum laki-laki atau politikus akan meraih suatu posisi puncak atau jabatan politik tertentu. Perempuan digunakan sebagai martir/ dikorbankan/ atau untuk senjata untukmencapai maksudnya.Misalnya, untuk kampanye mendukung suami di kalangan Dharma Wanita, ibu-ibu PKK, dan kelompok-kelompok pengajian ${ }^{6}$.

Persoalan-persoalan perempuan juga tidak terlepas dari peran agama yang bersumber dari Al-Qur'an dan Sunnah Rasul yang sangat beperan penting dalam menentukan hal-hal yang berkaitan dengan kehidupan baik berbangsa dan bernegara, di samping sebagai pedoman juga sebagai pengatur aktivitas pemeluk islam salah satunya mengatur persoalan perempuan. Persoalan ini kerap menjadi perbincangan menarik apabila kepemimpinan dipegang oleh seorang perempuan sehingga menghadirkan perdebatan-perdebatan di berbagai kalangan masyarakat.Persoalan perempuan merupakan hal yang aktual untuk dikaji dan telah berlangsung hampir seusia dengan lahirnya kebudayaan Islam, perbedaan antara laki-

5 Prihatinah, Tri Lisiani. 2010, Hukum dan Kajian Jender, Semarang, Badan Penerbit Universitas Diponegoro

6 PudjiAstuti, Tri Marhaeni. 2011. Konstruksi Gender dalam Realitas Sosial. Semarang: Unnes Press. 
laki dan perempuan ternyata masih menyimpan beberapa masalah, baik dari segi subtansi kejadian maupun peran yang diemban dalam masyarakat ${ }^{7}$.

Berdasarkan pemaparan tersebut, penelitian tentang representasi perempuanmuslim dalam politik menjadi polemik yang cukup menarik untuk diteliti. Bagaimana representasi perempuanmuslim dalam legislatif Kota Salatiga serta cara legislatif perempuan membangun dan mengembangkan komunikasi politik sekaligus hambatan dan tantangan apa saja yang telah mereka lalui. Selain itu pandangan islam tentang peran perempuan muslim dalam jabatan publik juga tidak kalah menariknya untuk dikaji. Karena kesetaraan gender dalam konteks keterwakilan perempuan sangatlah penting, apalagi juga dipengaruhi oleh konstruksi sosial, sistem hukum adat serta budaya dan juga agama.

\section{Representasi Perempuan Muslim dalam legislatif Kota Salatiga}

Kota Salatiga adalah sebuah kota di Provinsi Jawa Tengah yang terletak di tengah-tengah wilayah Kabupaten Semarang. Sebelah utara berbatasan dengan Kecamatan Pabelan dan Kecamatan Tuntang, sebelah timur berbatasan dengan Kecamatan Pabelan dan Kecamatan Tengaran, sebelah selatan berbatasan dengan Kecamatan Getasan dan Kecamatan Tengaran, sedangkan sebelah barat berbatasan dengan Kecamatan Tuntang dan Kecamatan Getasan.

Miniatur Indonesia adalah julukan bagi Kota Salatiga.Lima agama yang diakui Indonesia semuanya ada di Salatiga. Apabila di presentasekan maka 78.51\% penduduk Kota Salatiga memeluk agama Islam, pemeluk agama Kristen Protestan ada $16.32 \%$, untuk agama Buddha terdapat $0.21 \%$ pemeluk, sedangkan $0.09 \%$ memeluk agama Hindu.

Salatiga merupakan sebuah kota yang nyaman huni. Meski banyak perbedaan namun semua dapat hidup rukun berdampingan. Tak heran jika Salatiga mendapat gelar sebagai kota toleransi. Banyak sekali pendatang yang tinggal di kota ini. Entah untuk belajar, bekerja, ataupun memilih untuk menetap di kota indah ini. Dengan banyaknya pendatang tak heran jika banyak sekali budaya yang masuk di Salatiga. Namun semua itu tidak pernah mengusik ataupun mengurangi kedamaian kehidupan di kota ini.

Namun apabila ditelusuri lebih mendalam, terdapat satu kesenjangan yang masih terlihat dari Salatiga.Kesenjangan tersebut sudah terjadi lama dari tahun-tahun sebelumnya, yaitu keterwakilan perempuan dalam politik.Polemik tentang kesenjangan keterwakilan perempuan di dunia politik tidak hanya terjadi di Salatiga saja, namun hampir seluruh daerah di Indonesia juga mengalaminya. Bahkan DPR RI sebagai badan legislatif pusat pun juga mengalami hal yang sama.

Jaminan persamaan kedudukan laki-laki dan perempuan khususnya di bidang pemerintahan dan hukum telah ada sejak diundangkannya Undang-Undang Dasar 1945, 17 Agustus 1945, Pasal 27 ayat (1), menyebutkan bahwa: "Segala warga negara bersamaan kedudukannya di dalam hukum dan pemerintahan dan wajib menjunjung

\footnotetext{
${ }^{7}$ Nasruddin Umar.Argumen Kesetaraan Gender Persfektif Al-Qur'an (Jakarta: Paramadina, 2001), Cetakan ke-2
} 


\section{Qawwãm•Volume 13 Nomor 2, Desember 2019}

hukum dan pemerintahan itu dengan tidak ada kecualinya”.

Secara tegas hak perempuan untuk berpolitik dijamin dalam Konvensi tentang Penghapusan Segala Bentuk Diskriminasi terhadap Perempuan (Convention on the Elimination of All Forms of Discrimination against Women/CEDAW). Konvensi ini telah diratifikasi oleh Pemerintah Indonesia melalui Undang-Undang Nomor 7 Tahun 1984 tentang Pengesahan Konvensi mengenai Penghapusan Segala Bentuk Diskriminasi terhadap Wanita atau lebih dikenal dengan Konvensi Perempuan pada 24 Juli 1984. Sebelumnya Pemerintah Indonesia telah menandatangani konvensi tersebut pada 29 Juli 1980 saat mengikuti Konferensi Perempuan se-Dunia ke II di Kopenhagen.

Posisi keterwakilan politik perempuan di indonesia baru 17,8\%, dalam konteks global jauh dibawah negara-negara lain. Sepuluh negara terbesar tingkat keterwakilan politik perempuan antara lain Rwanda (56,3\%), Andorra(50\%), Kuba (45,2\%), Swedia (44,7\%), Republik Seychelles (43,8\%), Finlandia (42,5\%), Afrika Selatan (42,3\%), belanda (40,7\%), Nikarugua (40,2\%) dan Islandia (39,7\%) (Suwarko, 2014: 244-245).

DPRD merupakan lembaga perwakilan rakyat daerah dan berkedudukan sebagai unsur penyelenggaraan pemerintah daerah yang memiliki fungsi legilasi, anggaran, dan pengawasan (Siswanto, 2008: 67). Apabila dianalisis secara kuantitatif representasi perempuan di lembaga legislatif masih naik turun sejak pemilu tahun 1955-2014. Untuk lebih jelasnya, dibawah ini di paparkan tabel keterwakilan perempuan di DPR RI ${ }^{8}$

Jumlah Anggota Legislatif Perempuan DPR RI

\begin{tabular}{|c|c|c|}
\hline Periode & Perempuan & Laki-laki \\
\hline $1955-1956$ & $17(6,3 \%)$ & $272(93,7 \%)$ \\
\hline Konstituante 1955-1959 & $25(5,1 \%)$ & $488(94,9 \%)$ \\
\hline $1971-1977$ & $36(7,8 \%)$ & $460(92,2 \%)$ \\
\hline $1982-1987$ & $29(6,3 \%)$ & $460(93,7 \%)$ \\
\hline $1987-1992$ & $65(13 \%)$ & $500(87 \%)$ \\
\hline $1992-1997$ & $62(12,5 \%)$ & $500(87,5 \%)$ \\
\hline $1997-1999$ & $54(10,8 \%)$ & $500(89,2 \%)$ \\
\hline $1999-2004$ & $46(9 \%)$ & $500(91 \%)$ \\
\hline $2004-2009$ & $61(11,09 \%)$ & $489(88,9 \%)$ \\
\hline $2009-2014$ & $103(18 \%)$ & $457(82 \%)$ \\
\hline
\end{tabular}

Sumber: Andriana, 2012:32

8 Andriana, N. e. 2012. Perempuan, Partai Politik, dan Parlemen : Stud i Kinerja Anggota Legislatif Perempuan di Tingkat Lokal. Jakarta. PT Gading Intri Prima 
Dari data tersebut menunjukkan bahwa keterwakilan perempuan di parlemen (DPR) masih tetap memprihatinkan, tidak seimbang dengan jumlah partisipasi pemilih perempuan dan populasi penduduk perempuan di Indonesia.Sampai dengan periode selanjutnya yaitu 2014-2019, representasi perempuan dalam lembaga legislatif hanya mencapai 97 orang atau setara dengan $17,3 \%$ saja. Hal ini menunjukkan bahwa keterwakilan perempun masih belum mencapai kuota 30\%.

Dalam UU No. 10 Tahun 2008 tentang Pemilihan Umum Anggota DPR, DPD, DPRD disebutkan dalam pasal 20 tentang kepengurusan partai bahwa “ kepengurusan partai politik tingkat provinsi dan kabupaten/ kota sebagaimana dimaksud dalam pasal 19 ayat (2) dan ayat (3) disusun dengan memperhatikan keterwakilan perempuan paling rendah 30\% (tiga puluh perseratus) yang diatur dalam AD dan ART partai politik masing”. Partai politik merupakan wadah untuk menciptakan kesetaraan dan keadilan gender.Dalam berbagai aspek kehidupan bernegara dan berbangsa. Partai politik telah pula diberikan kepercayaan dalam affirmative action, yaitu menguatnya pemberdayaan politik perempuan di bidang politik $^{9}$

Sampai saat ini keterwakilan perempuan di parlemen masih sangat timpang.Ketimpangan keterwakilan perempuan tidak hanya terjadi pada parlemen pusat, namun juga terjadi pada DPRD Kota Salatiga. Untuk lebih jelasnya dapat dilihat pada table 2 di bawah ini:

Jumlah Anggota Legislatif Perempuan DPRD Kota Salatiga

\begin{tabular}{|c|c|c|}
\hline Periode & Perempuan & Laki-laki \\
\hline $2004-2009$ & $5(20 \%)$ & $20(70 \%)$ \\
\hline $2009-2014$ & $7(28 \%)$ & $18(72 \%)$ \\
\hline $2014-2019$ & $7(28 \%)$ & $18(72 \%)$ \\
\hline
\end{tabular}

Sumber: Majalah Jiwaraga DPRD Kota Salatiga Edisi perdana, Edisi 1 tahun 2009, Edisi II tabun 2014

Dari tujuh anggota legislatif perempuan muslimtersebut mempunyai motivasi yang sama yaitu ingin memenuhi 30\% kuota perempuan. Tujuan utama mereka adalah untuk menunjukkan bahwa perempuan muslimjuga mampu berperan aktif dalam ranah publik yaitu politik. Dengan bekal pendidikan politik dari masingmasing partai yang mereka dapatkan sebelum mencalonkan diri, tentu mereka sudah siap bekecimbung di dunia politik dan mampu menjadi wakil rakyat.

Tampaknya harapan aktivis perempuan untuk mewujudkan persamaan di bidang politik masih jauh dari kenyataan.Hal ini setidaknya dapat dilihat dari kuantitas maupun kualitas perempuan di parlemen nasional dan daerah belum signifikan.Artinya, jumlah perempuan yang duduk di lembaga legislatif masih jauh dari yang dicita-citakan (di bawah kuota 30\%).Di samping itu, perempuan yang

\footnotetext{
${ }_{9}^{9}$ Sastriyani, Siti Hariati. 2009. Gender and Politic. Yogyakarta : Tiara Wacana.
} 


\section{Qawwãm•Volume 13 Nomor 2, Desember 2019}

menduduki posisi strategis dalam kepengurusan parpol juga sangat sedikit. Hal ini berdampak pada proses pencalegan dan keterwakilanperempuan di parlemen. Dengan demikian, paling tidak ada dua persoalan perempuan dalam politik yaitu masalah partisipasi perempuan yang masih rendah di ruang politik dan masalah belum adanya platform partai yang secara konkret membela kepentingan perempuan.

Representasi perempuan dalam politik di Indonesia masih sangat jauh dari harapan para pejuang emansipasi perempuan. Para aktivis perempuan, akademisi perempuan, LSM, tokoh-tokoh perempuan yang selama ini telah memperjuangkan kesetaraan gender di daerah. Isu kesetaraan gender tidak hanya mengajak perempuan untuk berpartisipasi aktif dalam dunia politik tetapi juga untuk mengangkat derajat perempuan yang selama ini sering dianggap tidak bisa apa-apa dan hanya berlindung di bawah ketiak suami.

Dengan dikeluarkannya UU No. 10 Tahun 2008 tentang Pemilihan Umum anggota DPR, DPD, dan DPRD yang didalamnya memuat tentang kuota pemenuhan perempuan pada lembaga legislatif sebanyak 30\% sehingga dengan diberlakukannya kuota 30\% terhadap perempuan dalam bidang politik diharapkan mampu mewakili aspirasi kaum perempuan dalam parlemen di indonesia. Selanjutnya UU No. 10 thn 2008 digantikan dengan UU No. 8 tahun 2012 yang memuat hal yang sama. Hal tersebut merupakan upaya pemerintah dalam bidang politik terutama untuk pencapaian kesetaraan gender. Meskipun demikian, ruang gerak perempuan dalam panggung politik masih jauh dari keadilan dan kesetaraan.

Dengan diberlakukannya syarat pemilihan umum yang mengharuskan keterwakilan perempuan sebesar 30\%, hal ini dapat mengakibatkan partai politik hanya sekedar untuk memenuhi syarat kuota $30 \%$ untuk perempuan agar dapat ikut melaksanakan pemilu tanpa mempertimbangkan kualitas dari perempuan yang akan duduk sebagai wakil rakyat di parlemen.

Kenyataan di lapangan memang benar adanya, bahwa anggota legislatif perempuan yang dengan sengaja diminta oleh partai untuk memenuhi kuota $30 \%$ keterwakilan perempuan di partai tersebut sehingga dapat ikut serta dalam pemilu. Menurut YS menjelang pemilihan umum tahun 2014 kemarin, ada anggota partai politik yang memintanya untuk bergabung di partainya dengan tujuan agar dia mau untuk mencalonkan dirinya menjadi calon legislatif (YS, 2019:5). Hal ini menunjukkan bahwa betapa kurangnya keterwakilan perempuan dalam dunia politik. Ada dua nilai yang dapat kita ambil dari kedaan tersebut. Pertama nilai kurangnya partisipasi perempuan dalam politik yang tidak sesuai dengan kesetaraan gender yang gencar digaungkan. Kedua nilai betapa pentingnya keterwakilan perempuan bagi partai politik demi lancarnya sebuah pemilu.

Pada dasarnya memang bukan hal yang salah apabila sebuah partai meminta atau memasukkan perempuan dalam keanggotaannya agar dapat mengikuti pemilu. Namun pemasalahan yang terjadi adalah ada satu anggota legislatif perempuan yang sama sekali tidak mempunyai dasar ilmu politik. Dia berasal dari ibu rumah tangga biasa yang kesehariannya hanya dirumah (YS, 2019:8).Hal ini tentu menjadi tantangan tersendiri bagi dia yang dicalonkan dan partai yang mengusungnya. Karena apabila dia memang jadi, maka akan banyak hal baru yang harus dia pelajari. 
Begitupun partai pengusungnya yang harus benar-benar memberikan pendidikan politik bagi calon legislatifnya.

Namun ada juga legislatif perempuan yang memang tidak pernah terjun di dunia politik karena sebelumnya dia adalah pegawai negeri sipil, namun setelah pensiun dia memberanikan diri mendatangi sebuah partai dan menyatakan bahwa dia ingin bergabung di partai tersebut untuk mencalonkan diri sebagai calon legislatif. Alasan utamanya adalah untuk memenuhi kuota $30 \%$ yang telah diupayakan pemerintah untuk mengangkat kesetaraan gender di Indonesia. Namun selain itu dia sebenarnya penasaran dan ingin mempelajari politik untuk mengetahui alasan kenapa pemenuhan kuota perempuan yang hanya diberatkan 30\% saja susah sekali untuk terpenuhi (DS, 2019:7).

Meskipun begitu nyatanya ketiga anggota legislatif perempuan lainnya mengaku telah mendapatkan pendidikan politik yang cukup dari partainya. Pendidikan politik sangat perlu bagi calon legislatif terlebih bagi mereka yang sebelumnya sama sekali tidak pernah berkecimbung di dunia politik. Penguatan bekal tentang dasar-dasar ilmu politik harus benar-benar dikuatkan sehingga mereka paham betul apa saja tugas dan tanggung jawabnya menjadi wakil rakyat.

Banyak hal yang sudahanggota dewan lakukan demi meningkatkan kualitas perempuan. Mereka aktif membangun Dawis (Dasa Wisma), PKK (Pemberdayaan Kesejahteraan Keluarga), perkumpulan ibu-ibu pengajian, dan lain sebagainya yang ada di lingkungannya. Meskipun tidak bisa berkontribusi secara aktif, namun mereka selalu memberikan ide-ide kreatif dan inovatif pada setiap kegiatan yang ada (AT, 2019:17). Bahkan di daerah Dukuh-Sidomukti, YS membentuk Salatiga online center. Salatiga online center merupakan sebuah media online untuk memasarkan produk-produk buatan masyarakat Salatiga.Hal ini dia lakukan untuk menunjukkan kerja nyatanya dalam usaha membangun masyarakat agar lebih maju (YS, 2019:19).

Tidak dinafikan bahwa ada beberapa perempuan Salatiga yang ingin maju dalam segala bidang, maka penempatan posisi perempuan pada legislatif di Kota Salatiga menjadi sangat penting. Hal ini merupakan bagian dari kehidupan berdemokrasi dan transparansi dalam penyelenggaraan negara. Keterlibatan kaum perempuan di bidang politik, khususnya di legislatif akan memberikan keseimbangan dan mewarnai perumusan peraturan perundang-undangan, penganggaran dan pengawasan yang berspektif gender di Kota Salatiga.

Perempuan dalam bidang politik selayakanya mendapatkan perhatian dari segala pihak.Dengan demikian perempuan dapat menyuarakan aspirasinya dan berpartisipasi aktif dalam pembangunan.Dalam ranah politik, partisipasi perempuan yang masih sedikit hendaknya dapat didorong menjadi lebih banyak dan lebih aktif.

\section{Komunikasi Politik Perempuan}

Komunikasi adalah pengalihan informasi untuk memperoleh tanggapan; pengordinasian makna antara seseorang dan khalayak; saling berbagi informasi, gagasan , atau sikap; saling berbagi unsur-unsur perilaku, atau modus kehidupan, melalui perangkat-perangkat aturan; "penyesuaian pikiran, penciptaan perangkat simbol bersama di dalam pikiran pesertasingkatnya, suatu pengertian", "suatu peristiwa yang dialami secara internal, yang murni personal" yang dibagi dengan 


\section{Qawwãm•Volume 13 Nomor 2, Desember 2019}

orang lain; atau "pengalihan informasi dari satu orang atau kelompok kepada yang lain, terutama dengan menggunakan simbol". Bahkan ada definisi yang menyatakan apa komunikasi itu dengan mengatakan apa yang bukan: "komunikasi bukan sekedar penerusan informasi dari suatu sumber kepada publik; ia lebih mudah dipahami sebagai penciptaan kembali gagasan-gagasan informasi oleh publik jika diberikan petunjuk dengan simbol, slogan atau tema pokok ${ }^{10}$.

Politik adalah siapa memperoleh apa, kapan, dan bagaimana; pembagian nilainilai oleh yang berwenang; kekuasaan dan pemegang kekuasaan; pengaruh; tindakan yang diarahkan untuk mempertahankan dan atau memperluas tindakan lainnya. Politik mencakup sesuatu yang dilakukan orang; politik adalah kegiatan (Nimmo, 2005: 8).Dalam buku ini, politik merupakan kegiatan orang secara kolektif yang mengatur perbuatan mereka di dalam kondisi jasmani, bakat, emosi, kebutuhan, citacita, inisiatif, perilaku, dan sebagainya ${ }^{11}$.

Dari kedua konsep: komunikasi dan politik; maka komunikasi politik adalah suatu proses dan kegiatan-kegiatan yang membentuk sikap dan perilaku politik yang terintegrasi ke dalam suatu sistem politik dengan menggunakan seperangkat simbolsimbol berarti. Pengertian tersebut menunjukkan pada sikap dan perilaku seluruh individu yang berada dalam lingkup sistem politik, sistempemerintahan atau sistem nilai baik sebagai pemegang kekuasaan maupun sebagai masyarakat untuk terwujudnya suatu jalinan komunikasi antara pemegang kekuasaan (pemerintah) dengan masyarakat yang mengarah kepada sikap-sikap integratif.

Dari pengertian komunikasi politik tersebut, maka dapat dipahami bahwa terdapat strategi yang seharusnya ada ketika berkomunikasi secara politik.Bila dikaitkan dengan keterwakilan perempuan dalam bidang politi, maka hendaknya dari pihak partai politik memiliki strategi komunikasi politik bagi kader perempuannya.

Seperti yang diungkapkan Rush dan Althoff ${ }^{12}$ bahwa komunikasi politik memainkan peranan yang amat penting di dalam suatu sistem politik. Ia memerankan elemen dinamis, dan menjadi bagian yang menentukan dari prosesproses sosialisai politik, partisipasi politik, dan rekruitmen politik. Keterbukaan terhadap komunikasi politik dapat mempengaruhi orang untuk secara aktif terlibat dalam politik disatu pihak, dan di pihak lain, komunikasi politik juga bisa menekan partisipasi politik.

Strategi komunikasi dalam kaitan dengan partisipasi perempuan dan keterwakilan mereka di lembaga legislatif bisa dikelompokkan menjadi dua, yaitu strategi komunikasi politik perempuan dan strategi komunikasi politik partai politik. Strategi komunikasi perempuan dilakukan melalui counter komunikasi politik. Counter komunikasi politik tentu saja bukan hanya dilakukan oleh politisi

10 Nimmo, Dan. 2005. Komunikasi Politik, Khalayak dan Efek. Bandung. PT Remaja Rosdakarya.

11 Nimmo, Dan. 2005. Komunikasi Politik, Khalayak dan Efek. Bandung. PT Remaja Rosdakarya.

12 Rush, Michael \& Phillip Althoff. 2005. Pengantar Sosiologi Politik. Jakarta : PT Raja GrafindoPersada. 
perempuan tapi juga harus melibatkan politisi laki-laki ${ }^{13}$.

Menurut Pawito ${ }^{14}$ secara umum komunikasi politik dipandang sebagai proses.Komunikasi politik merupakan kegiatan yang terus-menerus berlangsung. Artinya, apa yang terjadi sekarang sebenarnya merupakan kelanjutan dari apa yang terjadi sebelumnya dan semua akan disambung dengan apa yang terjadi di waktu yang akan datang. Sebagai suatu proses, komunikasi politik dapat dipahami dengan melibatkan setidaknya lima unsur: (a) pelibat/aktor/partisipan, (b) pesan, (c) saluran, (d) situasi/konteks, dan (e) pengaruh/efek (Pawito, 2018: 5) dengan penjelasan sebagai berikut :

a. Pelibat (aktor/partisipan)

Pelibat atau aktor komunikasi politik adalah semua pihak yang terlibat atau mengambil peran dalam proses penyampaian dan penerima pesan. Aktor komunikasi politik dapat berupa perseorangan atau individu, kelompok, organisasi, lembaga, ataupun pemerintah.

b. Pesan

Telah ditemukan sebelumnya bahwa suatu komunikasi dapat dikatakan sebagai komunikasi politik apabila pesan yang saling dipertukarkan di antara partisipan, setidaknya sampai tingkat tertentu, memiliki signifikan dengan politik.Karakter dari pesan komunikasi politik senantiasa memiliki keterkaitan dengan politik.

c. Saluran (channe)

Saluran (channe) komunikasi politik dapat diibaratkan seperti jaringan pembuluh yang harus dipilih oleh seorang dokter ketika hendak memasukkan obat atau vaksin ke dalam sistem tubuh sorang pasien.Dalam komunikasi politik, kebijakan-kebijakan disebarluaskan kepada publik, tuntutan-tuntutan dan aspirasiaspirasi dirumuskan dan kemudian disampaikan, serta pendapat atau sikap-sikap dibentuk dan disuarakan.

d. Konteks

Situasi atau konteks komunikasi politik adalah keadaan dan kecenderungan lingkungan yang melingkupi proses komunikasi politik. Dalam arti luas, yang dimaksudkan dengan situasi atau konteks pada dasarnya adalah sistem politik di mana komunikasi politik berlangsung dengan segala keterkaitannya dengan nilainilai, baik filsafat, ideologi, sejarah, ataupun budaya. Dengan kata lain, komunikasi politik berlangsung dalam konteks sistem politik tertentu dengan segala aturan main serta tata nilai dan norma-norma yang berlaku pada suatu masyarakat atau bangsa yang mungkin berbeda dengan sistem politik masyarakat atau bangsa lain.

e. Pengaruh (effect)

Beberapa komunikasi politik mempunyai efek segera (immediate effect, shortterm effect), efek jangka panjang (long-term effect).

Dari pengertian komunikasi politik tersebut, maka dapat dipahami bahwa

13 Mukarom, Z. (2008). Perempuan dan Politik : Studi Komunikasi Politiktentang keterwakilan Perempuan di Legislatif. Media Tor.Vol. 9. No. 2, Desember: 257-269.

14 Pawito. 2007. Penelitian Komunikasi Kualitatif. Yogyakarta. Pelangi Aksara. 


\section{Qawwãm•Volume 13 Nomor 2, Desember 2019}

terdapat strategi yang seharusnya ada ketika berkomunikasi secara politik.Bila dikaitkan dengan keterwakilan perempuan dalam bidang politik, maka hendaknya dari pihak partai politik memiliki strategi komunikasi politik bagi kader perempuannya. Hal ini menunjukkan bahwa pentingnya pendidikan komunikasi politik bagi perempuan agar mempunyai keterampilan dan keberanian dalam menyuarakan pendapat dan isu gender di parlemen.

Konsep komunikasi politik dimaksudkan sebagai proses transmisi informasi yang relevan secara politis dari satu bagian sistem politik kepada sistem politik yang lain, (Karl W Deutsch, dalam Rush dan Althoff, 2005 : 252). Komunikasi politik sendiri bukanlah suatu bentuk komunikasi spesifik dan terpisah dari komunikasi secara umum.Oleh karena itu, pola-pola dasarnyapun mengikuti pola-pola komunikasi sosial. Adapun model komunikasi politik secara sederhana hampir sama dengan model komunikasi secara umum, seperti dalam gambar berikut :

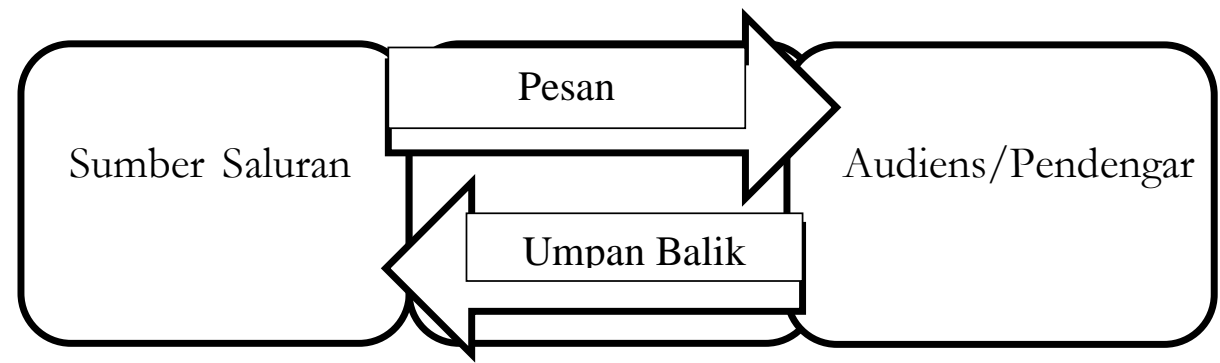

Model Komunikasi, Sumber : (Rush dan Althoff, 2005 : 253).

Unsur suatu sistem komunikasi dalam gambar tersebut terdiri dari : sumber (pesan, atau informasi), pesan, penerima informasi (audiens) dan suatu proses yang dikenal sebagai "umpan balik". Artinya dalam bentuk yang paling sederhana, proses komunikasi terdiri dari pengirim, pesan, dan penerima.Suatu tindakan komunikasi bermula dari si pengirim.Karena itu, kualitas komunikasi sebagai besar tergantung dari keterampilan si pengirim.Ia harus tahu isi pesan yang ingin disampaikannya, siapa penerimanya, dan dengan sarana apa pesan itu harus disampaikan. Kemudian tanggung jawab final dari si pengirim ialah mencari feedback atau umpan balik dan mengevaluasinya secara hati-hati. ${ }^{15}$

Jadi dalam suatu sistem komunikasi politik, sumber yang dimaksudkan adalah seseorang calon dalam pemilihan suatu jabatan politik; pesannya merupakan serangkaian usul politik; salurannya berupa siaran televisi, radio, surat kabar atau bahkan berbicara secara langsung; pendengarnya adalah anggota kelompok pemilih yang kebetulan memperhatikan; sedangkan umpan-baliknya adalah persetujuan atau ketidaksetujuan terhadap asal-usulnya.

Komunikasi politik memiliki pola-pola, antara lain pola komunikasi vertikal (dari atas ke bawah dan sebaliknya, misalnya dari pemimpin masyarakat kepada rakyat yang dipimpin atau sebaliknya), pola komunikasi horizontal (komunikasi antara individu yang satu dengan individu yang lain, atau antara kelompok yang satu

\footnotetext{
${ }^{15}$ Maran, Rafael Raga. 2001. Pengantar Sosiologi Politik. Jakarta : PT. RinekaCipta
} 
dengan kelompok yang lain), pola komunikasi formal (komunikasi melalui jalur-jalur organisasi formal), dan pola komunikasi informal (komunikasi melalui pertemuan atau tatap muka langsung, tidak mengikuti prosedur atau jalur-jalur formal yang berlaku dalam suatu organisasi).

Tanpa adanya komunikasi politik yang efektif, maka aktivitas politik akan kehilangan bentuk. Untuk itu, sumber pesan, misalnya seorang calon presiden, atau seorang calon legislatif dituntut untuk menyampaikan pesanyang jelas kepada seorang pendukungnya dan masyarakat luas.Di samping itu, calon yang bersangkutanpun harus tahu saluran atau sarana penyampaian informasi yang tepat. Dengan demikian dia pun boleh berharap untuk memperoleh umpan balik yang tepat pula. ${ }^{16}$

Pada konteks calon legislatif perempuan dalam melakukan komunikasi politik, termasuk kampanye kepada para konstituennya (pemilih), dia tentu mengingingkan umpan balik yang tepat.Tentu saja keinginan pada caleg ini adalah agar konstituen tersebut memilih mereka sebagai anggota legislatif, sehingga menghasilkan akumulasi suara yang banyak hingga mereka akhirnya dapat melenggang sebagai anggota legislatif terpilih.

Hasil penelitian memperlihatkan, jargon ataupun pesan yang disampaikan oleh para caleg perempuan ini adalah bersifat umum, yaitu isu tentang pemberantasan kemiskinan, janji untuk berjuang bagi peningkatan kehidupan yang lebih baik bagi masyarakat tempat caleg dipilih dan lain-lain.Jarang sekali para calon legislatif ini yang spesifik menyampaikan pesan/isuisu perempuan.Menurut RW salah satu informan, kampanye termasuk juga slogan serta atribut khusus yang spesifik perempuan tidak berperan banyak dalam menjaring suara (RW, 2019:16).Pada dasarnya yang lebih dipentingkan oleh rakyat adalah aksi nyata dalam membantu dan membela masyarakat (YS, 2019:16).

Sarana atau media yang digunakan oleh perempuan untuk berkomunikasi, selain melakukan komunikasi secara langsung melalui pertemuan dan kampanye terbuka seperti lewat arisan dan pengajian, juga berupa pembagian stiker, kaos dan jilbab (AT, 2019:12). Adapun, media massa, baik itu elektronik maupun cetak tidak digunakan oleh para caleg perempuan untuk berkampanye, para informan juga beranggapan media ini tidak berperan banyak dalam meloloskan para caleg perempuan ke legislatif. Para caleg berdalih, media massa kurang efektif dalam menjaring konstituen, mengingat konstituen menengah bawah memang tidak bahkan jarang memperhatikan iklan politik khususnya iklan politik caleg di televisi tanpa mengenal langsung siapa sebenarnya caleg tersebut.

YS mengatakan bahwa dia lebih banyak menfokuskan diri untuk menjaring suara pada masyarakat kelas menengah bawah, berpendapat bahwa model kampanye yang efektif untuk menjaring suara, khususnya untuk masyarakat kelas menengah bawah adalah melalui kampanye "door to door" (YS, 2019:12). Sedangkan media massa seperti poster dan lain sebagainya kurang begitu efektif karena masyarakat perlu mengenal secara langsung (DM, 2019:2)

Beberapa informan lebih memfokuskan diri pada masyarakat kelas menengah

${ }^{16}$ Ibid. Pengantar Sosiologi Politik 


\section{Qawwãm•Volume 13 Nomor 2, Desember 2019}

bawah karena kampanye pada masyarakat kelas menengah atas, sedikit mengalamai kendala, masyarakat ini memang agak sulit bahkan tidak bisa dipengaruhi, atau dalam bahasa informan "masyarakat ini sudah punya pendirian masing-masing, kalau mau masuk ke mereka, taktik dan strategi harus benar-benar jitu” (DS, 2019:12).

Komunikasi politik dan perempuan memiliki strategi yang seharusnya dapat mendorong perempuan untuk berpolitik sehat. Perempuan mendapatkan kesempatan dalam berbicara dan menyuarakan pendapat. Dengan demikian kiprah perempuan di legislatif dapat terlihat signifikan dalam menyuarakan isu gender.

Tantangan yang terberat bagi calon legislatif perempuan datang dari sesama para perempuan itu sendiri. Bagaimana kemampuan dia untuk bersaing dengan anggota dewan yang lainnya (RY, 2019:19). Tantangan lainnya adalah adanya ketakutan perselisihan karena perbedaan partai, tingkat pendidikannya, tingkat pemahaman dan kesadaran akan pentingnya suara mereka terwakili dengan memadai, dan tingkat pandangan mengenai politik itu sendiri, tentang anggapan bahwa politik itu buruk dan kotor serta sudut pandang dari nilai - nilai agama. Ketakutan akan adanya perbedaan partai dapat mempengaruhi perbedaan pemikiran dan pola pandang suatu masalah sehingga dapat menimbulkan persaingan (HS, 2019:19).

Pemahaman makna dari politik yang berperspektif perempuan harus di pahami terlebih dahulu, yang menjadi platform bagi dirinya sendiri dalam memperjuangkan perbaikan dan perubahan nasib perempuan di Kota Salatiga, sehingga bisa mengkritisi pandangan umum/maskulin bahwa politik adalah alat untuk memperoleh kekuasaan, daripada sebagai prasarana/sarana untuk memperbaiki keadaan Kota Salatiga.Partai politik adalah salah satu kendaraan arus utama (namun kendaraannya bukan milik pribadi, tetapi milik bersama anggota partainya/partai) yang berlaku di sistem pemilu, yang mau tak mau harus diikuti oleh para perempuan Kota Salatiga.

Bisa dikatakan perempuan Kota Salatiga kurang begitu berperan aktif dalam politik, padahal menurut aturan perundang-undangan salah satu persyaratan sebagai calon legislatif adalahkeaktifan calon legislatif.Kedudukan mereka dalam partai hanyalah menjadi anggota biasa, selalu tidak pernah menjadi orang yang diunggulkan.Kenyatannya perempuan cerdik cendikia atau perempuan teknokrat telah menjabat kedudukan tertentu di lembaga eksekutif dan yudikatif, seperti pegawai negeri sipil, hal yang tidak memungkinkan mereka masuk dalam lingkaran legislatif.Undang-undang telah menetapkan bahwa pegawai negeri sipil tidak boleh menjadi anggota partai politik.Hal ini tidak berarti bahwa tidak ada perempuan yang dapat memenuhi kualifikasi sebagai calon legislatif.

Keterwakilan perempuan muslim di DPRD Kota Salatiga belum sepenuhnya mampu menyuarakan isu-isu perempuan secara nyata. Hal ini ditunjukkan dari kurang adanya kegiatan atau gerakan khusus yang diinisiasi oleh para legislatif perempuan untuk menanggapi permasalahan-permasalahan keperempuanan yang terjadi selama mereka menjabat.Para legislatif perempuan kurang menyuarakan aspirasi konstituen perempuan. Mereka lebih cenderung menggunakan isu-isu yang sifatnya umum seperti perekonomian dan lain sebagainya. 


\section{SIMPULAN}

Berdasarkan hasil penelitian dan pembahasan mengenai representasi perempuan muslimdi DPRD Kota Salatiga dapat diambil simpulan sebagai berikut:

1. Secara kuantitatif keterwakilan perempuan dalam DPRD Kota Salatiga belum mencapai 30\%. DPRD Kota Salatiga memiliki sebanyak 25 anggota dewan, 7 diantaranya adalah perempuan yakni sekitar 28\%. Hal ini hampir mencapai $30 \%$. Namun apabila ditinjau secara kualitatif, jumlah 28\% tersebut cukup mampu bersaing dengan anggota dewan laki-laki. Hal ini dibuktikan dengan adanya jabatan penting yang diduduki oleh legislatif perempuan yaitu sebagai wakil ketua DPRD. Namun dalam memperjuangkan aspirasi masyarakat yang bersentuhan dengan ketidakadilan gender, legislatif perempuan masih belum mampu mewujudkannya.

2. Komunikasi politik perempuan di DPRD Kota Salatiga lebih menggunakan sistem komunikasi interpersonal baik dengan konstituen maupun pemerintah. Tidak ada hambatan yang berarti selama proses komunikasi berlangsung. Namun tidak bisa dipungkiri bahwa tantangan utama bagi legislatif perempuan adalah mampu bersaing dengan legislatif laki-laki dan hal itu membutuhkan kecakapan komunikasi politik. Selain kecakapan komunikasi, dalam berkomunikasi politik legislatif perempuan membutuhkan mental yang kuat dan juga strategi yang tepat, sehingga mereka mampu menyalurkan aspirasinya dan tidak hanya mengikuti forum.

\section{DAFTAR PUSTAKA}

Akbar \& Usman. 2009. Metode Penelitian Sosial. Jakarta. BumiAksara.

Andriana, N. e. 2012. Perempuan, Partai Politik, dan Parlemen: Studi Kinerja Anggota Legislatif Perempuan di Tingkat Lokal. Jakarta. PT Gading Intri Prima

Anugrah, Astrid. Keterwakilan Perempuan Dalam Politik, Jakarta: Pancuran Alam Jakarta. 2009.

Ardial. 2010. Komunikasi Politik. Jakarta Barat, PT Indeks.

Azis, Asmaeny. 2013. Perempuan di Persimpangan Parlemen : Studi dalam Perspektif Hukum. Yogyakarta :Rangkang Education.

Basrowi \& Suwandi. 2008. Memahami Penelitian Kualitatif. Jakarta. Rineka Cipta.

Huzaemah Tahido Yanggo. 2009 Fikih Perempuan Kontemporer. Jakarta: Ghalia Indonesia.

Majalah Jiwaraga DPRD Kota Salatiga Edisi perdana, Edisi1 tahun 2009, Edisi II tahun 2014 


\section{Qawwãm•Volume 13 Nomor 2, Desember 2019}

Maran, Rafael Raga. 2001. Pengantar Sosiologi Politik. Jakarta : PT. RinekaCipta.

Mukarom, Z. (2008). Perempuan dan Politik : Studi Komunikasi Politiktentang keterwakilan Perempuan di Legislatif. Media Tor.Vol. 9. No. 2, Desember: 257-269.

M.QuraishShihab, Wawasan al-Qur'an: Tafsir Maudhu'i Atas Berbagai Persoalan Umat, (Bandung: Mizan, 1996), Cetakanke-13.

Nasruddin Umar.Argumen Kesetaraan Gender Persfektif Al-Qur'an (Jakarta: Paramadina, 2001), Cetakan ke-2

Nimmo, Dan. 2005. Komunikasi Politik, Khalayak dan Efek. Bandung. PT Remaja Rosdakarya.

Nugroho, Riant. 2008. Gender dan Administrasi Publik, Yogyakarta, Pustaka Pelajar.

Nur Imam Subono, Menuju Representasi Politik Perempuan yang Lebih Bermakna. Jurnal Sosial Demokrasi, Edisi 6, tahun 2, Juni-Agustus 2009

Pawito. 2007. Penelitian Komunikasi Kualitatif. Yogyakarta. Pelangi Aksara.

Prihatinah, Tri Lisiani. 2010, Hukum dan Kajian Jender, Semarang, Badan Penerbit Universitas Diponegoro.

PudjiAstuti, Tri Marhaeni. 2011. Konstruksi Gender dalam Realitas Sosial. Semarang: Unnes Press.

Richard S. Katz dan Wiliam Cotty. 2010. Handbook PartaiPolitik (Terjemahan). Bandung : Nusa Media.

Rush, Michael \& Phillip Althoff. 2005. Pengantar Sosiologi Politik. Jakarta : PT Raja GrafindoPersada.

Sastriyani, Siti Hariati. 2009. Gender and Politic. Yogyakarta : Tiara Wacana.

Sugiyono. 2011, Metode Penelitian Kuantitatif, Kualitatif, dan R\&D. Bandung : Afabeta.

S. Nasution. 2002. Metode Research Penelitian Ilmiah. Jakarta. Bumi Aksara.

Surbakti, Ramlan. 2010. Memahami Ilmu Politik. Jakarta. Gramedia Pustaka Utama.

Sulaiman, King F. 2013. Sistem Bikameral Dalam Spektrum Lembaga Parlemen Indonesia. Yogyakarta: UII Press.

Syafiie, InuKencana. 2013. Ilmu Pemerintahan. Semarang. Bumi Aksara. 
Bira Farida Nurul Layli, Muna Erawati

"Zipper System dan Eksistensi Peran Perempuan dalam Koncah Politik", http://google.co.id, diakses tanggal 8 Maret 2011. 